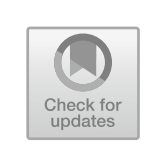

\title{
Switzerland: Formalizing Banking Supervision in the Aftermath of a Crisis, Better Late Than Never
}

\subsection{INTRODUCTION}

Banking has long been identified as a key sector in Swiss economy. The Swiss financial center grew extensively during the twentieth century, and it became a turntable for international capital. The rapid growing significance of the international activities of Swiss banks was disproportionate to the size of the country, its demographic importance, or its economic and industrial power. Despite the international reputation of Swiss banking (both in positive and negative aspects), only few studies have addressed the historical development of banking regulation and financial supervision specifically: following Bänziger's pioneering study of the development of banking supervision (Bänziger 1986), post-2008 contributions have largely renewed the historical research on Swiss financial regulation (Giddey 2012, 2019; Mazbouri and Schaufelbuehl 2015; Straumann and Gabathuler 2018).

This chapter will focus on the process that led to the introduction and successful implementation of banking supervision during the twentieth century. As shown below, banking supervision was introduced rather late in the aftermath of a severe crisis due to the strong resistance of bankers. During a long period, at least until the 1980s, official banking supervision merely consisted in de jure controls of commercial banks. The effectiveness of the supervisory activities of the federal agency in charge of supervision was improved progressively, thus leading to the completion of the formalization process.

(C) The Author(s) 2022

E. Hotori et al., Formalization of Banking Supervision, https://doi.org/10.1007/978-981-16-6783-1_6 


\subsection{Development of Swiss Banking System}

At the turn of the twentieth century, Switzerland gradually developed into an international financial center (Mazbouri 2005). The Swiss banking system rested on two main types of banks: the cantonal banks and the so-called big banks (Mazbouri et al. 2012). The cantonal banks are mostly government-owned commercial banks, whose assets are guaranteed by the cantons. Established in successive waves during the nineteenth century, their business area stretched from mortgage credit (and savings deposits) to commercial lending. The "big banks," on the other hand, were founded in the second half of the nineteenth century, on the model of the French Credit mobilier. They were meant to finance large investment projects, such as railway construction or manufacturing industry. In 1933, on the eve of the formalization of banking regulation, there were eight big banks: the Schweizerische Kreditanstalt (Zurich, established in 1856), the Schweizerischer Bankverein (Basel, 1872), the Schweizerische Bankgesellschaft (Zurich, result of a merger in 1912), the Schweizerische Volksbank (Berne, 1869), the Eidgenössische Bank (Zurich, 1863), the Basler Handelsbank (Basel, 1862), the Banque d'Escompte Suisse (Geneva, founded 1855, merger in 1931), and the Leu \& Co (Zurich, founded in 1755 , joint-stock company in 1854). ${ }^{1}$

In addition to the cantonal and big banks, other secondary banking categories also shaped the Swiss financial center: local and regional banks, savings banks, or private banks. Private banking houses, frequently originating from 18th century trading companies, specialized in wealth management, but also participated in other activities such as bond issuing, thanks to their international network of contacts (Mazbouri 2020). All in all, despite the division between different types of financial companies, the Swiss banking system has been marked by a great versatility and a strong tendency toward mixed "universal" banking. Commercial credits, collection of savings, mortgage credits, and even the issuing of state bonds were not restricted to one specific category of banks. Another outstanding feature was the comparatively low degree of concentration of the Swiss banking sector, at least between the end of the nineteenth century and the 1960s (Ritzmann 1973: 108-115; Cassis 2001). The low market concentration was also fostered by the coexistence of three financial centers within Switzerland. At the turn of the twentieth century,

\footnotetext{
${ }^{1}$ Regarding the Swiss big banks, see Mazbouri (2016) for further details.
} 
Geneva, Basel, and increasingly Zurich emerged as the main financial centers of the country thanks to their respective specialization, their own stock exchange, and close international linkages.

The Swiss financial center, as it developed at the beginning of the twentieth century, was made of a polycentric territory-distributed between Zurich, Geneva, and Basel-based on the growth of two main actors: the big banks and the cantonal banks (Mazbouri et al. 2012: 472). When compared internationally, Swiss banking, from a very early stage, succeeded in keeping a strong position in the niche market of cross-border capital management (Farquet 2018: 15-46). Swiss banking position as a hub for international transactions and a safe haven for foreign capital during the First World War strengthened this underlying feature, and laid the foundations for the tremendous growth of the second part of the twentieth century. However, recent research suggests that the transformation of Switzerland into an international tax haven, which, in turn, contributed to the establishment of an international financial center, dates back to the nineteenth century (Guex 2021).

A distinctive feature of the Swiss financial center was the late creation of a central bank. The establishment of the Swiss National Bank in 1907 was the result of a 15-years-long political process, and put an end to a decentralized monetary regime, with a large number of issuing banks. The Swiss National Bank was shaped as a semi-public institution: it is a joint-stock company, but some of the governing bodies are elected by the federal government and its monetary policy is confined within the framework of the National Bank Act of 1905 (Guex 1993; Bordo and James 2007). As noted by Grossmann, the Swiss National Bank does not fit the general conclusion that younger central banks were more likely to become banking supervisors than their older counterparts (Grossman 2010a, b: 162-167). The absence of a supervising function within the competence of the central bank established in 1907 left a vacuum that would not be filled before the start of formalization of banking supervision in 1934 .

\subsection{Financial Crisis and Enactment of THE BANKing ACT OF I934}

Although the first Banking Act at the federal level was only enacted in November 1934, the first attempt to pass a law on commercial banking 
dates back to $1914 .^{2}$ Previously, the only form of regulation on banking in effect were cantonal decrees on savings banks and on the establishment of cantonal banks, introduced in the second half of the nineteenth century. ${ }^{3}$ In 1914, following a severe crisis resulting in the failure of a share of 10-15 percent of Switzerland banking institutions (50-69 out of 449 banks were deleted from the company register in 1910-1914), the federal government delegated the drafting of a bill on the supervision of banking companies (Wetter 1918; Ritzmann 1973: 105). The legislative proposal, known as "Landmann bill" after its author, Julius Landmann, professor of economics in Basel, met with considerable opposition from the banking community when confidentially discussed in 1916. Among bankers, the prospect of the state control over financial activity awakened fears of tarnishing the international role of the Swiss financial center as a safe haven for capital, since during the period of the war a lot of capital poured into Switzerland from the belligerent countries (Farquet 2012). Although the main provisions of the Landmann bill did not involve a radical change in banking activities, but only included basic regulatory provisions, such as a licensing system and the setting up of a federal Office for Banks, the draft bill was abandoned in 1917 due to joint action on the part of the Swiss Bankers Association and the Swiss National Bank (Mazbouri and Schaufelbuehl 2015).

In 1931 the European banking crisis hit the major Swiss banks hard. The introduction of exchange controls as well as the freezing of Swiss assets in Germany and central Europe created serious problems for the financial institutions that were heavily involved in the countries concerned (Perrenoud et al. 2002: 81-82; Halbeisen 2001). Swiss banks held a large share of German external debt, and the freezing of those assets caused a considerable devaluation of the invested funds. Overall, the strategy of the affected banks was to reduce their assets in countries with transfer restrictions. The governmental efforts to try to enact a Banking law resumed soon after the outbreak of the financial crisis in Switzerland. Yet, during a first phase (1931-1933), the discussions between financial, political, and administrative elites moved slowly. The banking representatives tried to avoid a law on commercial banking, by insisting on two alternatives solutions: first was an informal and private agreement with the central bank,

\footnotetext{
${ }^{2}$ For further details on the history of Swiss banking supervision, see Giddey (2019).

${ }^{3}$ These regulations remain outside the scope of this book.
} 
for example on balance sheets' publications. Second was the insertion of a few provisions on banking supervision within the general corporate law.

Indeed, the first specific bill on commercial banking appeared to be doomed to suffer the same fate as the previous Landmann bill. In December 1933 the near-failures of two big banks, which were forced to ask for Confederation support in order to avoid bankruptcy, led to a change of course. Two large banks (the Banque d'Escompte Suisse and the Schweizerische Volksbank), which were suffering from the 1931 banking crisis and had invested a large share of assets in countries with transfer restrictions, had to ask for external bailout plans in order to avoid bankruptcy (Baumann 2007). On both occasions, the governmental rescue plan for the failing banks generated a rising political pressure in favor of banking legislation, since the plan involved the federal state acquiring of a stake equivalent to roughly a quarter of its expenditure for that year. The bailout plans had to be approved by the federal parliament, which compelled the banking representatives to make concessions. The Swiss bankers considered the passing of a law inevitable, and they participated actively in its preparation. The law-making process was marked, both in the pre-parliamentary committees and in the parliament, by the decisive influence of certain bank managers, such as the chief executive of Credit Suisse Adolf Jöhr. At the end of a rather short legislative process for Swiss habits, the Federal Law on Banks and Savings Banks was adopted in November 1934.

The enactment of the 1934 Banking Act represented the first step toward the formalization of banking supervision in Switzerland. For the first time, almost all commercial banks were subject to the same rules at the federal level. However, some financial intermediaries such as finance companies, private banks, and cantonal banks obtained a specific status, allowing them not to be subject to certain provisions. Entry conditions were not very strict: a bank could open its counters after fulfilling technical and administrative requirements. A licensing system-that is, allowing a supervisor to grant and revoke banking licenses or charters according to the compliance with regulation-was not provided for. Some prudential measures were implemented in the 1934 Banking Act: banks had to comply with an equity ratio and a liquidity ratio, but the minimal levels were low and the enforcement of the ratios did not involve a change in credit policy. Notably, bank secrecy-one of the most important competitive advantages for the Swiss financial center-was strengthened, given that Article 47 afforded it protection under criminal law (Guex 
2000). Preserving and even consolidating the secrecy of banking activities concomitantly with the passing of a law on banking supervision was also a message to foreign bank customers who might have feared state intervention. Overall, the banking regulation introduced in 1934 was more of a generalization of existing practices than a questioning of the system. No separation of commercial and investment banking was introduced, and the model of the mixed universal commercial bank remained untouched. ${ }^{4}$

\subsection{Organization of Swiss BAnking Supervision Agency}

The 1934 Banking Act set up the first nationwide supervision agency: the Federal Banking Commission (FBC), "eidgenössische Bankenkommission." Its main task was to ensure the effective application of the Banking Act. Among the more precise missions of the new organism, it had to give a ruling on which companies were subject to the law, recognize auditing bodies, agree on restructuring procedures for failing banks, verify compliance with liquidity and equity ratios, confirm the yearly audit of every bank, and establish regulations of limited scope.

Set up and financed by the federal government, the FBC was an executive body of public law enjoying considerable autonomy. Its broad independence was only nuanced by the fact that it had to submit an annual report to the federal government and that some of its decisions could be subject to administrative appeal to the Federal Supreme Court. The FBC formed an administrative novelty in Swiss institutions. Whereas the supervision of insurance companies had been carried out since 1885 by a federal office directly embedded in state administration, the FBC was a more independent agency, with regard to both the government and the central bank. Quite interestingly, the strong institutional separation between the FBC and the Swiss National Bank was also due to the fact that the latter was reluctant to being involved in the supervision, for fear that it would damage its relationship of trust with commercial banks. The first FBC board members in 1935 were a former Federal Councillor-i.e. Swiss head of state-(as chairman), a former director of the Swiss National Bank, a member of parliament, and two retired bank managers from the

\footnotetext{
${ }^{4}$ In 1971 the Banking Act was revised in the wake of the development of foreign banks in Switzerland. Yet the revision met with strong resistance, and thus only minor adjustments were made (Giddey 2013).
} 


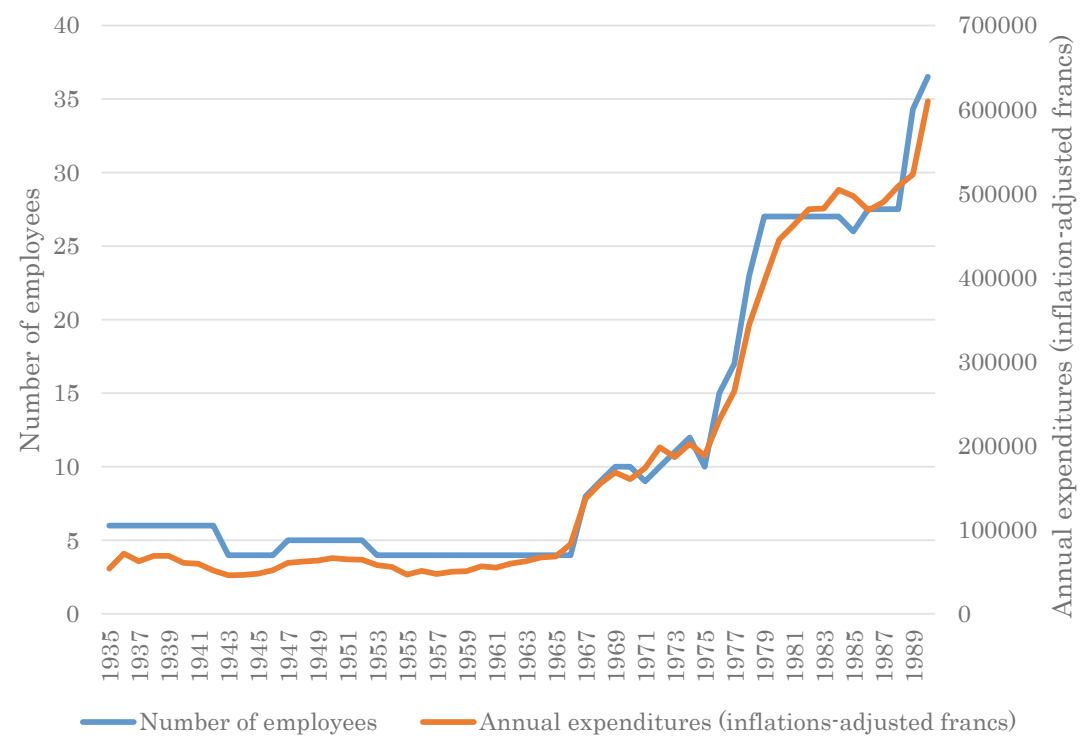

Fig. 6.1 Swiss Federal Banking Commission: staff and resources, 1935-1990 (Sources Giddey [2019: 250-251])

two biggest banks of the day. The composition of the commission did not change significantly over time (1935-1991). Out of five or seven members, there were former or active politicians (liberal and conservative), law or economics professors, former governors of the central bank, and former commercial bank managers. Most of the Swiss banking supervisors $(71 \%)$, exclusively university-educated men with an average age of 58 at appointment and 66 at retirement, had strong ties with the banking sector-board members, former managers of commercial banks, cantonal banks, Swiss national bank, auditing companies (Giddey 2019: 247). ${ }^{5}$

In addition to the members who only met on a part-time basis-on average once a month, the FBC had a permanent secretariat in charge of the day-to-day management of the supervision agency. The Banking Commission was poorly staffed and under-resourced (Fig. 6.1). The total number of employees of the Swiss banking supervision agency (including

\footnotetext{
${ }^{5}$ Biographical statistics are based on the 42 first members of the Federal Banking Commission (1935-1991).
} 
subordinate staff) ranged from 4 to 6 between 1935 and 1966. An increase occurred in the late 1960s, when the Commission was entrusted the supervision of investment funds; the late 1970s witnessed a second employee growth as a result of a governmental decision. The development of the financial resources of the FBC follows the same path, as staff salaries were the largest expense. It should be noted that the staff was very limited, even when compared nationally. In 1966, while the banking supervision agency employed only 6 persons, the Federal Bureau of Private Insurance had 29 employees and the Swiss National Bank employed over 400. Whereas the Swiss financial center enjoyed tremendous growth during the post-Second World War economic expansion, the administrative body in charge of its supervision lagged behind.

\subsection{Activities of Banking Supervision}

As a consequence of the structural weakness of the Swiss banking supervision agency, its actual activities were also limited. As a matter of fact, the 1934 Banking Act introduced a regulatory regime which made auditing companies as the cornerstone of the financial supervision. The private auditing firms were in charge of the on-site primary examination of the annual accounts and balance sheets. This examination consisted in the monitoring of the compliance of the bank's bookkeeping with banking regulation. This supervisory regime was indirect, since the main monitoring tasks were executed by private auditors. The state agency could only intervene in a second phase. In the view of the bankers who favored this solution, this system had the advantage of keeping the civil servants at bay in order to maintain a high level of secrecy. However, the indirect supervisory regime also highlighted the lack of independence between the supervised banks and the supervising auditing companies. Indeed, the main auditing companies who dominated the market of official banking auditing were established or taken over by the big banks, such as the Gesellschaft für Bankrevisionen, jointly created in 1934 by Credit Suisse and Schweizerischer Bankverein. Consequently, the reports produced by the auditing companies on the regulatory conformity were rather lenient. Applying great diligence sometimes meant losing a client/customer, since the banks were free to choose any approved auditing company.

The Federal Banking Commission's activities did not involve onsite examinations. The supervisory activities were restricted to repetitive administrative routine: registration of new banks, accounting reports 
collection, authorizing auditing companies, and discussing the management of failing banks. As a result of the indirect supervisory regime, the Banking Commission is kept informed of only a narrow part of the Swiss financial center's activities. The audit reports annually produced by the auditing companies were only transmitted to the FBC if the clarified breaches could not be resolved amicably by the bank and the auditing company. Between 1937 and 1970, the FBC dealt with auditing reports which concerned a share of banks varying between four and 22\% (Giddey 2019: 357). The vast majority of financially sound banks were completely off the radar. In the same vein, disciplinary measures were very rarely part of the regulatory framework of the Banking Commission. During its first 30 years of existence (1935-1965), the FBC filed only 16 complaints against non-compliant banks and refrained from using this disciplinary measure more often, as this step was seen as too drastic and prone to threaten the financial viability of the concerned bank. Legal complaints by the agency were thus considered measures of last resort.

In light of the very limited capacity of the Federal Banking Commission to grasp the supervision of the Swiss financial center, one might expect that the supervisors would redouble their efforts to change the regulatory framework in order to improve their resources and competences. During a first phase, between 1935 and 1965, it was not the case at all. Conversely, the Swiss banking supervisors, in line with the Bankers Association, opposed all the bills and plans that implied a formal amendment of the 1934 Act. They feared that opening up a public discussion on banking regulation could produce damaging or ineffective results. This strong defense of the status quo, both by the supervisors and the supervised, and despite established legal loopholes, explains why the first legislative revision of the Banking Act occurred as late as $1971 .{ }^{6}$

As a consequence, Switzerland provides an interesting case of an incomplete formalization of banking supervision during a long first phase. Indeed, even after the introduction of a federal law on commercial banking in 1934, only two of the three conditions, i.e., the enactment of a legal basis and the establishment of a supervisory agency, had been met. The effective enforcement activities by the supervision agency were still practically non-existent for a long time. During its first fifty years of existence, the Banking Commission was an empty shell which merely

${ }^{6}$ Yet, this amendment only consisted in minor changes. 
carried out administrative duties. It was not until the early 1980s, with the stepping up of the resources of the Banking Commission, that an actual implementation of state banking supervision could be achieved.

$$
* * *
$$

In summary, Swiss banking supervision was formalized with the enactment of the Banking Act in 1934. Considering the early development and international activities of Swiss banks, the adoption of a law on commercial banking was rather late in comparative perspective. This delay was partly due to the marked reluctance of Swiss leading bankers to state intervention in the sector as well as their successful dismissal of previous regulatory attempts.

The passage of the 1934 law was the result of the heavy banking crisis that affected Swiss banks in the early 1930s. The losses suffered and the governmental bailout plans adopted undermined the resistance of banking representatives to a specific Banking Act. However, previous self-regulatory arrangements persisted mainly between the central bank and the bankers' association. The 1934 law established a new supervisory actor, the Federal Banking Commission. Yet, this agency was not given adequate supervisory capacities in terms of resources and competences. Instead, the private auditing firms undertook the on-site primary examination of banks-the main auditing companies were under the influence of large banks. It was not until the 1980s that the resources of the supervisors were significantly improved to complete the formalization of banking supervision.

\section{REFERENCES}

Bänziger, H. 1986. Die entwicklung der bankenaufsicht in der Schweiz seit dem 19. jahrhundert. Bern/Stuttgart: Haupt.

Baumann, J. 2007. Bundesinterventionen in der bankenkrise 1931-1937. Eine vergleichende studie am beispiel der Schweizerischen Volksbank und der Schweizerischen Diskontbank. Doktorarbeit, Philosophische Fakultät, Dissertation, Universität Zürich.

Bordo, M., and H. James. 2007. From 1907 to 1946: A happy childhood or a troubled adolescence? In The Swiss National Bank, 1907-2007, ed. W. Abegg and E. Baltensperger, 29-107. Zürich: Neue Zürcher Zeitung Publishing. 
Cassis, Y. 2001. Introduction: A century of consolidation in European bankingGeneral trends. In A century of banking consolidation in Europe, ed. M. Pohl, T. Tortella, and H. Van Der Wee, 3-17. Aldershot: Ashgate.

Farquet, C. 2012. The rise of the Swiss tax haven in the interwar period: An international comparison. EHES Working Papers in Economic History 27: 1-40

- 2018. Histoire du paradis fiscal suisse. Expansion et relations internationales du centre offshore suisse au XXe siècle. Paris: Presses de Sciences Po.

Giddey, T. 2012. Gendarme ou médecin des banques? Les premières années d'activité de la Commission fédérale des banques (1935-1943). Traverse Revue d'histoire 3: 145-163.

- 2013. The regulation of foreign banks in Switzerland (1956-1972). In Foreign financial institutions and national financial systems, ed. M. Aspey, P. Hertner, and K. Kaczmar, 449-485. Frankfurt a.M: The European Association for Banking and Financial History.

- 2019. Histoire de la régulation des banques en Suisse (1914-1972). Genève: Librairie Droz.

Grossman, R.S. 2010a. The emergence of central banks and banking supervision in comparative perspective. In State and financial systems in Europe and the USA: Historical perspectives on regulation and supervision in the nineteenth and twentieth centuries, ed. S. Battilossi and J. Reis, 123-137. Burlington: Ashgate.

- 2010b. Unsettled account: The evolution of banking in the industrialized world since 1800. Princeton, NJ: Princeton University Press.

Guex, S. 1993. La politique monétaire et financière de la Confédération 19001920. Lausanne: Payot.

- 2000. The origins of the Swiss Banking Secrecy Law and its repercussions for Swiss federal policy. Harvard Business History Review 74 (2): 237-266.

- 2021. The emergence of the Swiss tax haven, 1816-1914. Business History Review, First View, 1-20.

Halbeisen, P. 2001. The banking crisis and its implications for Swiss banking legislation in the 1930s. In A century of banking consolidation in Europe, ed. M. Pohl, T. Tortella, and H.V.D. Wee, 102-120. Aldershot: Ashgate.

Mazbouri, M. 2005. L'émergence de la place financière suisse (1890-1913): Itinéraire d'un grand banquier. Lausanne: Antipodes.

- 2016. A retrospective illusion? Reflections on the "longevity" of Swiss big banks, 1850-2000. In Immortal banks: Strategies, structures and performances of major banks, ed. M. Lescure, 231-251. Genève: Librairie Droz.

Mazbouri, M. 2020. La banque privée comme métaphore: «vieille banque» et «banque nouvelle» en Suisse (1800-1930) (première partie). Schweizerische Zeitschrift für Geschichte 70 (1): 93-115. 
Mazbouri, M., S. Guex, and R. Lopez. 2012. Finanzplatz Schweiz. In Wirtschaftsgeschichte der Schweiz im 20. jahrbundert, ed. P. Halbeisen, M. Müller, and B. Veyrassat, 467-518. Basel: Schwabe.

Mazbouri, M., and J.M. Schaufelbuehl. 2015. A legislator under surveillance: The creation and implementation of Swiss banking legislation 1910-1934. European History Quarterly 45 (4): 662-688.

Perrenoud, M., R. López, F. Adank, J. Baumann, A. Cortat, and S. Peters. 2002. La place financière et les banques suisses à l'époque du national-socialisme: les relations des grandes banques avec l'Allemagne (1931-1946). Chronos Verlag 13.

Ritzmann, F. 1973. Die Schweizer banken: geschichte - theorie - statistik. Bern/Stuttgart: Haupt.

Straumann, T., and J. Gabathuler. 2018. Die entwicklung der Schweizer bankenregulierung. In Krisenfeste Schweizer banken? Die regulierung von eigenmitteln, liquidität und "too big to fail», ed. A. Jans, C. Lengwiler, and M. Passardi, 57-86. Zürich: Neue Zürcher Zeitung Publishing.

Wetter, E. 1918. Bankkrisen und bankkatastrophen der letzten Jahre in der Schweiz. Zürich: Orell Füssli.

Open Access This chapter is licensed under the terms of the Creative Commons Attribution 4.0 International License (http://creativecommons.org/licenses/ by $/ 4.0 /)$, which permits use, sharing, adaptation, distribution and reproduction in any medium or format, as long as you give appropriate credit to the original author(s) and the source, provide a link to the Creative Commons license and indicate if changes were made.

The images or other third party material in this chapter are included in the chapter's Creative Commons license, unless indicated otherwise in a credit line to the material. If material is not included in the chapter's Creative Commons license and your intended use is not permitted by statutory regulation or exceeds the permitted use, you will need to obtain permission directly from the copyright holder.

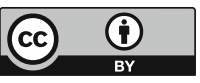

